\title{
Firewood harvest from forests of the Murray-Darling Basin, Australia. Part 2: Plantation resource required to supply present demand
}

\author{
P.W. West ${ }^{a, b}$, E.M. Cawsey ${ }^{c, *}$, J. Stol ${ }^{c}$, D. Freudenberger ${ }^{d}$ \\ ${ }^{a}$ School of Environmental Science and Management, Southern Cross University, Lismore, NSW 2480, Australia \\ bsiWest Consulting, 16 Windsor Court, Goonellabah, NSW 2480, Australia \\ 'CSIRO Sustainable Ecosystems, GPO Box 284, Canberra, ACT 2601, Australia \\ ${ }^{\mathrm{d}}$ Greening Australia, PO Box 74, Yarralumla, ACT 2600, Australia
}

\section{A R T I C L E I N F O}

\section{Article history:}

Received 5 February 2008

Accepted 29 February 2008

Available online 2 May 2008

\section{Keywords:}

Firewood

Murray-Darling Basin

Eucalypt

Plantations

\begin{abstract}
A B S T R A C T
The Murray-Darling Basin covers $1 \mathrm{M} \mathrm{km}^{2}$ and occupies most of inland, south-eastern, mainland Australia. Large areas have been cleared and are now used for agriculture. In this paper, estimates are made of the minimum area of Eucalyptus globulus plantation forests needed to be established in the Basin to supply $2.25 \mathrm{M}$ oven-dry tyr ${ }^{-1}$ of firewood annually, the amount of firewood harvested presently from the native forests which remain in the Basin. If plantations were established in higher rainfall areas along the eastern and southern boundaries of the Basin, it was estimated that a minimum of just over 200,000 ha of plantations would be required, grown on a 10-yr rotation. If plantations were restricted to less productive areas of lower rainfall $\left(<900 \mathrm{~mm} \mathrm{yr}^{-1}\right)$, or to areas where land clearing for agriculture has been particularly intensive, a minimum of just under 350,000 ha would be required, grown on an 11-yr rotation. If planting was restricted to soils in the Basin at high risk of salinisation from agriculture, which are generally in areas of lower rainfall, a minimum of about 600,000 ha would be required, grown on a 20 -yr rotation. It is considered that the practicalities of plantation establishment in the Basin would require appreciably larger areas of plantations than these minima.
\end{abstract}

(c) 2008 Published by Elsevier Ltd.

\section{Introduction}

The previous paper in this series [1] has described generally the Murray-Darling Basin and present concerns about the harvest of firewood from its native forests. The Basin is $1 \mathrm{M} \mathrm{km}^{2}$ in area and occupies most of inland, south-eastern, mainland Australia. Although extensively cleared for agriculture in times past, native forests still occupy at least $29 \%$ of its area. About $2-2.5 \mathrm{Mt}$ of firewood (all firewood amounts referred to in this paper are oven-dry weights) are harvested annually from these forests, mostly through collection of fallen, coarse woody debris.
There is concern that continued removal of coarse woody debris from the native forests of the Basin may prejudice its floral and faunal biodiversity. In [1], the possibility was considered of obtaining firewood by harvesting live trees from these native forests, instead of collecting coarse woody debris. The present work considers what area of forest plantations would be required to supply the present demand for firewood. These plantations would be established on land which has been cleared and would avoid completely the need for harvests from the native forests of the Basin.

Two factors are likely to restrict the feasibility of plantation establishment in the Basin. First, firewood is a product of

\footnotetext{
*Corresponding author. Tel.: +61262421628; fax: +61262421688.

E-mail address: margaret.cawsey@csiro.au (E.M. Cawsey). 0961-9534/\$- see front matter ๔ 2008 Published by Elsevier Ltd. doi:10.1016/j.biombioe.2008.02.018
} 
relatively low commercial value; it is often difficult to encourage land owners to grow plantations even for highvalue wood products [e.g. 2,3] and would be even more difficult for a low-value product such as firewood. Second, the productivity of plantations in the Basin will be relatively low. In the past, plantations have been established in regions of Australia where the annual rainfall is at least $800 \mathrm{~mm} \mathrm{yr}^{-1}$ and, to achieve the highest productivity, often above $1000 \mathrm{~mm}$ $\mathrm{yr}^{-1}$ [4]. Small areas in the easterly and southerly parts of the Basin have an annual rainfall as high as $1000 \mathrm{mmyr}^{-1}$. However, its rainfall declines progressively to less than $300 \mathrm{mmyr}^{-1}$ towards the arid interior of Australia; about $75 \%$ of the Basin has a rainfall of less than $750 \mathrm{~mm} \mathrm{yr}^{-1}$, sufficiently low to reduce plantation productivity appreciably.

However, there is increasing appreciation that plantations may offer environmental benefits in addition to their ability to supply wood. Particularly important is their role in ameliorating the environmental damage that has occurred, in some regions of Australia, through increasing salinity of the surface soil. This damage has resulted from rising soil water tables, after native forests have been cleared and replaced with shallow-rooted, agricultural crops [5]; parts of the Basin suffer from this problem. The establishment of deeper-rooted, plantation forest crops may assist in rehabilitation of the damaged soil by lowering the water table $[5,6]$. Other social, economic and environmental benefits of plantation forests include the possibility of crop diversification for struggling agricultural enterprises, enhancement of regional biodiversity and contributions to regional development [7].

Considerable research remains to be done to establish the practicalities of plantation development in the drier regions of Australia in general and the Basin in particular. There have been a number of trials undertaken, often in the context of rehabilitation of saline soils, to investigate the growth rates and/or the physiological attributes of various species, which might be appropriate for plantation development in these regions, including the Basin [e.g. 8-16]. Other work has examined the processing of wood from plantations in the Basin, although only in the context of sawn wood products and paper pulp, not firewood [17-20]. Some work has investigated the economic feasibility of plantations in the Basin, although only in the context of irrigated plantations for sawn wood or paper pulp $[18,21]$. Irrigation can be expected to increase plantation productivity substantially and has been considered also in the context of the disposal of sewage waste water in the Basin [22,23]. Much work remains to be done for the drier regions of Australia, to determine definitively which species will be most appropriate for plantations and what silvicultural practices will be necessary (see [5, Chapter 8]) to provide satisfactory growth, appropriate products and adequate environmental benefits.

The present work does not consider in any detail these practical issues, which will need to be addressed before forest plantations could become major suppliers of firewood from the Basin. Rather, it attempts simply to establish a benchmark, by estimating the minimum plantation area, which would be required to supply the amount of firewood, which is taken presently from the Basin. This should quantify the magnitude of the task of replacing, with plantation grown wood, the supply of firewood obtained presently from the native forests of the Basin.

\section{Identification of land areas suitable for plantation forestry}

The first step in this work was to identify where land suitable for plantation forestry occurs in the Murray-Darling Basin. GIS surfaces of the Basin were obtained, showing forest cover, forest type and land tenure (National Forest Inventory, Bureau of Rural Sciences, Australia), digital elevations, urban areas, rainfall and water courses (Geosciences Australia), areas at risk of site degradation by salinisation (National Land and Water Resources Audit, Bureau of Rural Sciences, Australia) and land productive capacity ( $\mathrm{Dr}$ D. Barrett, CSIRO Plant Industry, Australia). The measure of productive capacity was the maximum annual rate of net primary production of vegetation at a site, referred to here as 'NPP index'; this index is described in more detail in [1] and was determined using methods described in [24].

Land areas considered suitable for plantation forestry were assumed to

- be both cleared and privately owned (or leased). It was assumed that plantation forests would be established by private investors and environmental benefits would arise from planting previously cleared land,

- be less than $500 \mathrm{~km}$ from a capital city; the main market for firewood is in the capital cities and it was considered economically unfeasible to transport firewood further than this,

- have a slope no greater than $15^{\circ}$ and to be more than $50 \mathrm{~m}$ from streams or rivers; this should minimise the risks of environmental damage from soil disturbance during plantation operations,

- have an altitude above sea level of no more than $650 \mathrm{~m}$, an altitude considered generally in Australia above which temperatures are too low for successful plantation forestry, and

- have an NPP index of at least $5 \mathrm{tha}^{-1} \mathrm{yr}^{-1}$; as discussed in Section 3.2, a productive capacity below this was considered impractically low for plantation forestry.

Using the GIS surfaces, there was found to be $15.8 \mathrm{M}$ ha of such land. Its distribution across the Basin is shown in Fig. 1(a) and represents what was termed here Option 1 for land areas suitable for plantation forestry. Three other options were considered also, each reflecting different environmental considerations, which might be appropriate when undertaking a plantation programme in the Basin. Each of these other options involved putting an additional restriction on the land area determined for Option 1.

Option 2 included only areas where the annual average rainfall was less than $900 \mathrm{~mm} \mathrm{yr}^{-1}$. This option reflected a desire that water lost from the Basin through evapotranspiration from plantations should not come from the higher rainfall, most productive regions of the Basin. Generally, there seems to be little risk presently of environmental degradation through soil salinisation of land cleared for agriculture in 
a

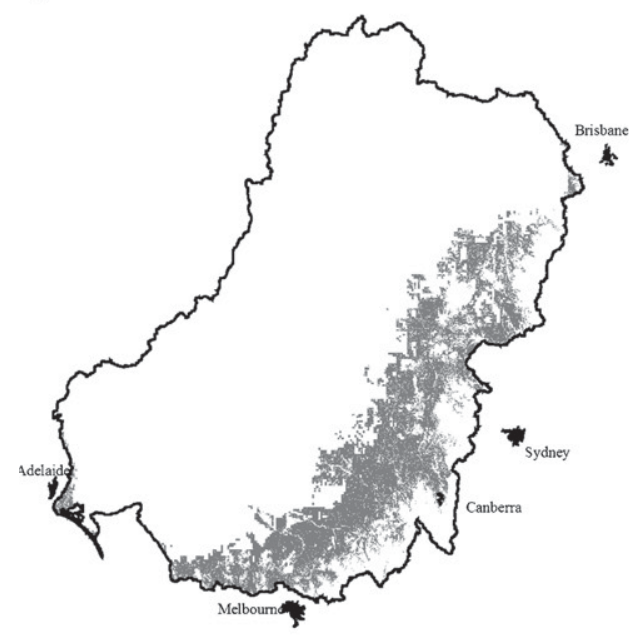

C

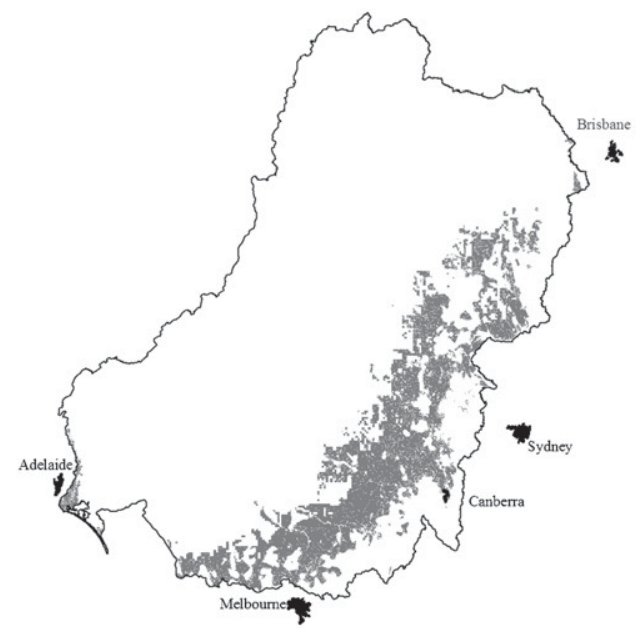

b

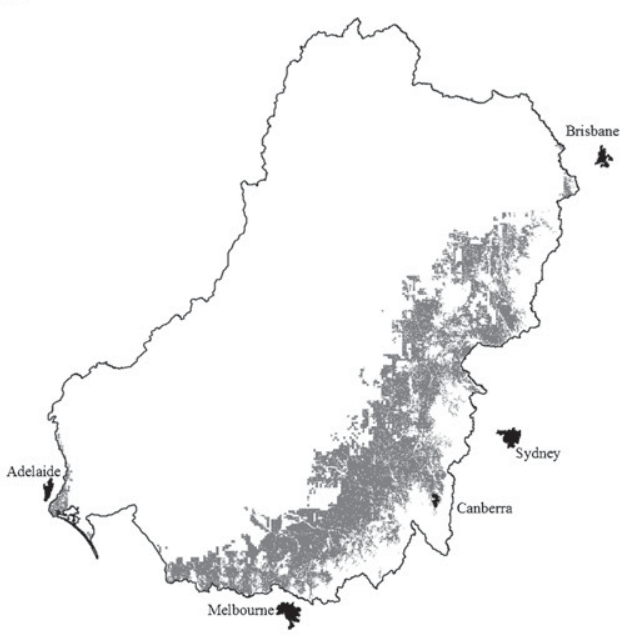

d
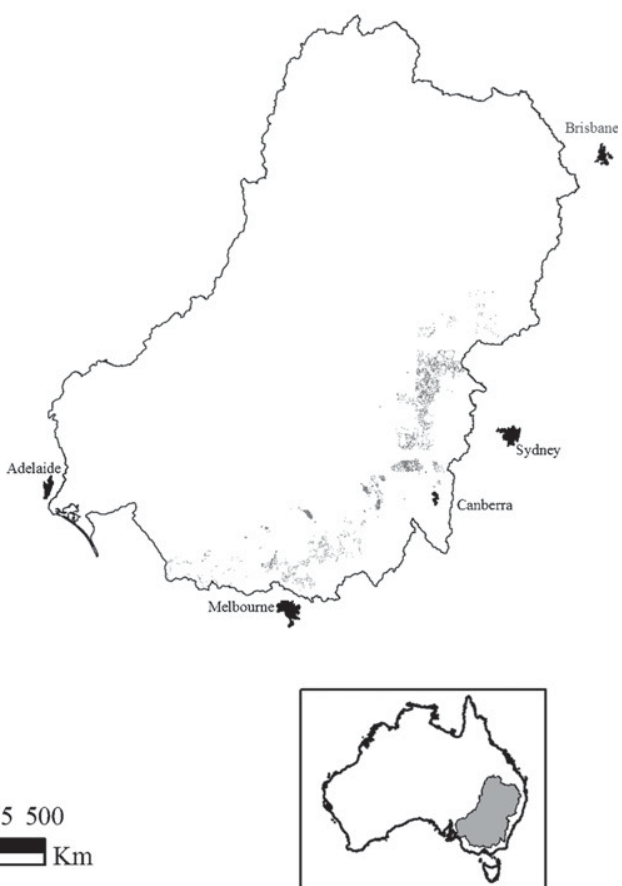

Fig. 1 - Distribution of privately owned, cleared land areas across the Murray-Darling Basin considered suitable for plantation forestry. (a) Option 1, (b) Option 2, which excludes areas from Option 1 with an annual rainfall in excess of $900 \mathrm{~mm} \mathrm{yr}^{-1}$, (c) Option 3, which includes only areas from Option 1 where the surrounding landscape has less than $30 \%$ of its area forested, and (d) Option 4, which includes only areas from Option 1, which are at high risk of site degradation due to salinisation.

these regions. As well, they supply relatively large quantities of water as run-off to rivers, water which will reduce river salinity concentrations and which would then be available for farm irrigation in drier parts of the Basin [25]. There were $15.5 \mathrm{Mha}$ of land suitable for this option. Its distribution across the Basin is shown in Fig. 1(b).

Option 3 included only areas from Option 1 where the general landscape had less than $30 \%$ of the land area forested with native forests. This option reflected a desire to establish trees in areas of the Basin, which have suffered more extensive land clearing in the past, areas which are more likely to have suffered loss of floral and faunal biodiversity.
There were $13.5 \mathrm{M}$ ha of land suitable for this option, as shown in Fig. 1(c).

Option 4 included only areas from Option 1, which are at higher risk of environmental degradation through soil salinisation. This option reflects a desire to avoid further degradation of the soils and water of the Basin. There were $0.9 \mathrm{M}$ ha of land suitable for this option, as shown in Fig. 1(d).

The land area for each of these four options was then stratified by its productive capacity, as assessed by NPP index, into classes with a width of $0.2 \mathrm{tha}^{-1} \mathrm{yr}^{-1}$. The maximum productive capacity that occurred in each of the four options was $14.0,13.0,12.6$ and $13.5 \mathrm{tha}^{-1} \mathrm{yr}^{-1}$, respectively. 


\section{Growth and yield of plantations}

\subsection{Growth and yield model}

Fundamentally necessary to determining the area of plantation forests needed in the Murray-Darling Basin to supply firewood is a method to estimate the wood yields that might be obtained from them. To date, there is insufficient experience of plantation forestry in the Basin to have available sufficient data to do this definitively. However, a readily available plantation forest growth and yield model system for Eucalyptus globulus may provide appropriate yield estimates. Extensive plantations of Eucalyptus globulus have been established in temperate regions of southern Australia and elsewhere in the world [26] and it may well be a species appropriate for plantations in the Basin [18-20]. Studies have been made of its wood properties and economic potential in small plantation areas already established there [17-21], although not in the context of firewood production. The calorific value of E. globulus wood, at $3 \mathrm{yr}$ of age, has been measured as $19.7 \mathrm{MJ} \mathrm{kg}^{-1}$ [27].

The model system for E. globulus plantations is described in [28]. It is available publicly as a computer package, called the 'Farm Forestry Toolbox', from Private Forests Tasmania, a state government authority. As inputs, the model system requires long-term, average daily weather information for a site being considered for a plantation (daily solar radiation, daylength, maximum and minimum temperatures, rainfall, pan evaporation and average vapour pressure deficit). As well, soil variables required are the soil water storage capacity between field capacity and wilting point, an indication of whether the soil is well or poorly drained and an index of fertility. The drainage and soil fertility indices are discussed in more detail in [29].

Given these inputs, the model system then predicts the productive capacity of an E. globulus plantation growing on the site. The measure of site productive capacity used is 'stand site index'. This is defined as the average height, which will be attained by the 50 tallest trees $\mathrm{ha}^{-1}$ in a stand at $15 \mathrm{yr}$ of age; stand site index is a measure of site productive capacity used extensively in forestry science [30]. For the present work, it was determined that stand site index $(S, m)$, as used by the growth and yield model, could be predicted from NPP index $\left(P_{B}, t_{h a}^{-1} \mathrm{yr}^{-1}\right)$, as

$S=1.239 P_{B}^{1.299}$

The model system predicts also the wood volume yields, which will be obtained from the plantation at any age during its lifetime; the user may specify the log size-class(es) for which these volume estimates are to be made. The user may specify also that thinning be undertaken at any stage of the plantation development and the model will predict the wood yields at each thinning, as well as those obtained at clearfelling.

\subsection{Applying the growth and yield model}

In using the model, it is necessary to specify a stocking density at establishment for the plantation; initial stocking density can be expected to affect both the total production of a stand and the average diameter of the trees, hence the wood volumes obtained in any particular log size-class [31]. For the present work, it was assumed that stocking density at establishment of plantations in the Basin would be 1111 stems ha ${ }^{-1}$ (equivalent to a square spacing of $3 \times 3 \mathrm{~m}^{2}$ ), a planting density used commonly in forest plantations in Australia.

It was assumed also that all stem wood produced by the plantation, up to a small end diameter of $10 \mathrm{~cm}$, would be harvested as firewood; any log with a diameter smaller than this was assumed to be too small for use as firewood. To convert wood volumes predicted by the model to weight of firewood, it was assumed that E. globulus stems have a basic density of $0.51 \mathrm{tm}^{-3}$, an average value for young plantation grown E. globulus determined by Raymond and MacDonald [32, as quoted in Ref. 33]. It was assumed also that plantations being grown for firewood would not be thinned at any stage during their life-span; since the value of firewood logs is independent of their diameter (as long as it is above the minimum), it was felt that no advantage would be gained in plantations for firewood through the acceleration of diameter growth rates from thinning. Lastly, it was assumed that the clear-felling harvest of a plantation would occur at the age when at least $80 \%$ (a value chosen arbitrarily) of the total stem wood volume of the trees in the plantation was of a size sufficiently large to be used as firewood (in any harvest operation there will be inevitably parts of the stem near the top of the tree, which have too small a diameter for use as any wood product).

Given these assumptions, Fig. 2 shows predictions from the model of the time course of development of total stand stem wood biomass (all plant biomass amounts referred to in this paper are oven-dry weights) and stand firewood yield from plantations of E. globulus growing on sites with NPP indices of 11.2 or $7.6 \mathrm{tha}^{-1} \mathrm{yr}^{-1}$. In both these examples, results are shown to the age at which firewood yield first exceeded $80 \%$ of total stem biomass. These results suggest a rotation age of $10 \mathrm{yr}$ would be appropriate for the stand of higher productivity and $20 \mathrm{yr}$ for that of lower productivity. Corresponding firewood yields at those two ages would be 105 and $78 \mathrm{tha}^{-1}$, respectively.

It should be borne in mind that it is assumed implicitly in the E. globulus growth and yield model that appropriate silvicultural practice is applied in any plantation, consistent with the standards considered normal in plantation forestry in Australia today [31]. In particular, this means sites will have had appropriate cultivation before planting, browsing by animals (such as kangaroos or possums) will have been controlled, weeds will have been controlled regularly during the first few years of plantation growth to avoid competition with the trees and that some fertilisation may have been done on particularly infertile sites. If these silvicultural standards are not maintained, wood yields from plantations may be appreciably lower than those predicted here.

Eq. (1) predicts that a site with an NPP index of $5 \mathrm{tha}^{-1} \mathrm{yr}^{-1}$ will grow an E. globulus plantation with a site index of $10 \mathrm{~m}$. This is the lowest productive capacity for which the E. globulus model is able to predict plantation production reliably. For the present work, it was considered that sites 


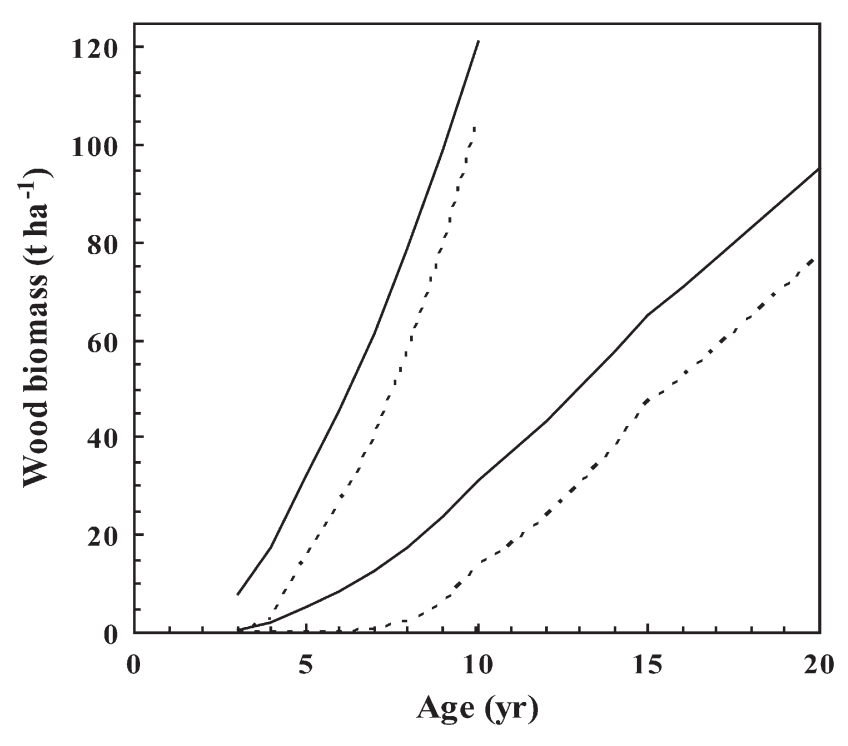

Fig. 2 - Time course of development of stand stem wood total biomass (-) and firewood yield (- - -) for a Eucalyptus globulus plantation growing on sites with an NPP index of 11.2 $\mathrm{t} \mathrm{ha}^{-1} \mathrm{yr}^{-1}$ (upper two lines) or $7.6 \mathrm{tha}^{-1} \mathrm{yr}^{-1}$ (lower two lines), as predicted the $E$. globulus plantation growth and yield model of [28].

with a productive capacity lower than this would simply be inappropriate for plantation establishment. This led to the constraint used in Section 2 that areas suitable for plantation forestry should have an NPP index of $5 \mathrm{tha}^{-1} \mathrm{yr}^{-1}$ or more.

\section{Plantation areas required to supply present firewood demand}

Given the areas of the Murray-Darling Basin suitable for plantation forestry under Options 1-4 and their stratification by NPP index (Section 2), it was straightforward to apply the E. globulus growth and yield model (Section 3 ) to predict the total amount of firewood, which could be produced from $E$. globulus plantations in any stratum. In doing so, it was assumed that plantations would be established annually over a proportion $1 / r$ of any stratum, where $r$ (yr) is the rotation length for firewood production in that stratum. This would ensure that a long-term, steady annual supply of firewood would be obtained as equal areas of plantations reach their clear-felling ages annually in any one stratum.

To determine the minimum area of plantations required to supply the present demand of $2.25 \mathrm{Mtyr}^{-1}$ of firewood (the midpoint of the range 2-2.5 $\mathrm{M} \mathrm{tyr}^{-1}$, which it is believed is taken presently from the Basin), it was assumed that any land of higher productive capacity would be planted before any land of lower productive capacity. Given this, Table 1 shows the minimum plantation areas, which would be required for each of the four area options. Also shown is the average rotation length of the plantations in each option and their average firewood yield at clear-felling.
Table 1 - Minimum E. globulus plantation area required in four area options (Fig. 1) of the Murray-Darling Basin, to yield an annual supply of $2.25 \mathrm{Mtyr}^{-1}$ of firewood

\begin{tabular}{cccc}
\hline Option & $\begin{array}{c}\text { Minimum } \\
\text { area } \\
\text { (M ha) }\end{array}$ & $\begin{array}{c}\text { Average } \\
\text { rotation } \\
\text { length (yr) }\end{array}$ & $\begin{array}{c}\text { Average firewood } \\
\text { yield at clear- } \\
\text { felling }\left(\mathrm{tha}^{-1}\right)\end{array}$ \\
\hline 1 & 0.21 & 10 & 105 \\
2 & 0.33 & 11 & 75 \\
3 & 0.35 & 11 & 72 \\
4 & 0.58 & 20 & 78 \\
\hline
\end{tabular}

Also shown are the average rotation length and firewood yield at clear-felling of the plantations in each option.

The results show that the smallest possible area of E. globulus plantations required is $0.21 \mathrm{M}$ ha. As might be expected, this was for Option 1, which included the most productive land available in areas of the Basin with higher annual rainfalls. The land areas available for Options 2 and 3 had lower overall productivity than that available for Option 1, hence both those options would require larger minimum plantation areas ( 0.33 and $0.35 \mathrm{M}$ ha, respectively). Option 4 included land considerably less productive than the other three and so would require the largest minimum plantation area $(0.58 \mathrm{M} \mathrm{ha})$. The rotation lengths of $10-11 \mathrm{yr}$ for Options 1-3 are similar to those generally considered appropriate in Australia for eucalypt plantation forestry for the production of lower value wood products (principally wood chips for paper making in plantations in southern Australia). The rotation length of $20 \mathrm{yr}$ for Option 4 would generally be considered too long to produce a low-value forest product; such a rotation length would usually be countenanced only if there were other values, such as environmental benefits, deriving from the plantations.

\section{Discussion}

Based on the information on forest types in the GIS surface obtained from the National Forest Inventory (Section 2), there are presently only 1536 ha of privately owned hardwood plantations in the Murray-Darling Basin. The present results (Table 1) suggest it will require an area of plantations in the range $200,000-600,000$ ha at least, if the firewood supplied presently from native forests of the Basin is to be replaced entirely by plantation grown wood. The final area would depend on the choice made as to which of Options 1-4 was chosen to define the land most appropriate for plantation forestry. At the very minimum, it would require establishment of slightly more than 20,000 ha yr $^{-1}$ for $10 \mathrm{yr}$, if the most productive land in the Basin was available for plantations. If planting was restricted to sites at risk of soil salinisation (Option 4), 29,000 ha would have to be established annually for $20 \mathrm{yr}$ to achieve the estate size required.

It should be appreciated also that the plantation areas estimated here are the minimum necessary for each of the four options. In determining those areas, it was assumed that the most productive land under each option would be 
available for plantation establishment. This will certainly not be so. Many land owners will prefer to continue to use their land for its present agricultural purposes. This means that some less productive land would have to be used for plantations, with concomitant increases in the plantation areas required to meet the desired firewood supply.

It was assumed also that plantations are established in the Basin wholly for firewood production. As discussed in Section 1, such plantations are unlikely to be viable commercially, because of the low value of firewood. It is likely that private growers would be encouraged to establish plantations for firewood production only if they received some sort of subsidy for the environmental benefits the plantations will offer the Basin as well.

From this and the previous work in this series [1], it seems it is possible theoretically to supply the present demand for firewood from privately owned land in the Basin by coarse woody debris collection from native forests, or by removal of live trees from native forests or by establishment of plantations. However, the different aspirations of the many private land owners and the environmental requirements of land management in the Basin will make it impractical to restrict firewood production to only one of these three methods. Rather, some compromise involving all three is likely to be necessary.

\section{Acknowledgments}

This work was commissioned by the Australian Commonwealth Department of Environment and Heritage. It was financed both by them and CSIRO Sustainable Ecosystems.

R E F E R E N C E S

[1] West PW, Cawsey EM, Stol J, Freudenberger D. Firewood harvest from forests of the Murray-Darling Basin, Australia. Part 1: Long-term, sustainable supply available from native forests. Biomass and Bioenergy 2008, this issue, doi:10.1016/ j.biombioe.2008.02.017

[2] Race D, Curtis A. Socio-economic considerations for regional farm forestry development. Australian Forestry 1997;60:233-9.

[3] Schirmer J, Kanowski P, Race D. Factors affecting adoption of plantation forestry on farms: implications for forestry development in Australia. Australian Forestry 2000;63:44-51.

[4] Turnbull JW, Pryor LD. Choice of species and seed source. In Hillis WE, Brown AG, editors. Eucalypts for wood production. Melbourne: CSIRO; 1978. p. 6-65.

[5] Lambert M, Turner J. Commercial forest plantations on saline lands. Melbourne: CSIRO; 2000.

[6] Marcar NE, Khanna PK. Reforestation of salt-affected and acid soils. In: Nambiar EKS, Brown AG, editors. Management of soil, nutrients and water in tropical plantation forests. Monograph no. 43, Canberra:Australian Council for International Agricultural Research; 1997. p. 481-525.

[7] Gerrand A, Keenan RJ, Kanowski P, Stanton R. Australian forest plantations: an overview of industry, environmental and community issues and benefits. Australian Forestry 2003;66:1-8.

[8] Biddiscombe EF, Rogers AL, Greenwood EAN, De Boer ES. Growth of tree species near salt seeps, as estimated by leaf area, crown volume and height. Australian Forest Research 1985;15:141-54.

[9] Eastham J, Scott PR, Steckis RA, Barton AFM, Hunter LJ, Sudmeyer RJ. Survival, growth and productivity of tree species under evaluation for agroforestry to control salinity in the Western Australian wheatbelt. Agroforestry Systems 1993;21:223-37.

[10] Greenwood EAN, Biddiscombe EF, Rogers AL, Beresford JD, Watson GD. Growth of species in a tree plantation and its influence on salinity and groundwater in the $400 \mathrm{~mm}$ rainfall region of south-western Australia. Agricultural Water Management 1995;28:231-43.

[11] Morris J, Mann L, Collopy J. Transpiration and canopy conductance in a eucalypt plantation using shallow saline groundwater. Tree Physiology 1998;18:547-55.

[12] Cramer VA, Thorburn PJ, Fraser GW. Transpiration and groundwater uptake from farm forest plots of Casuarina glauca and Eucalyptus camaldulensis in saline areas of southeast Queensland, Australia. Agricultural Water Management 1999;39:187-204.

[13] Mazanec Z. Nine year results from a Eucalyptus camaldulensis Denh provenance trial in the Wellington catchment of Western Australia. Australian Forestry 1999;62:166-72.

[14] Mazanec Z. Thirteen year results from a Spotted Gum provenance trial in the Wellington catchment of Western Australia. Australian Forestry 1999;62:315-9.

[15] White DA, Turner NC, Galbraith JH. Leaf water relations and stomatal behaviour of four allopatric Eucalyptus species planted in Mediterranean southwestern Australia. Tree Physiology 2000;20:1157-65.

[16] Dumbrell IC, McGrath JF. Growth and nutrient relationships of juvenile Pinus pinaster grown on ex-farmland in Western Australia. Australian Forestry 2003;66:137-44.

[17] Clark NB, Read SM, Vinden P. Effects of drought and salinity on wood and craft pulps from young plantation eucalypts. Appita Journal 1999;52:93-7.

[18] Clark NB, Rawlins WHM. Prospects for pulpwood from the Murray Darling Basin. Appita Journal 1999;52:203-12.

[19] Washusen R, Blakemore P, Northway R, Vinden P, Waugh G. Recovery of dried appearance grade timber from Eucalyptus globulus Labill grown in plantations in medium rainfall areas of the southern Murray-Darling Basin. Australian Forestry 2000;63:277-83.

[20] Washusen R, Waugh G, Hudson I. Appearance product potential of plantation hardwoods from medium rainfall areas of the southern Murray-Darling Basin. Green Product Recovery. Australian Forestry 2000;63:66-71.

[21] Sands P, Rawlins W, Battaglia M. Use of a simple plantation productivity model to study the profitability of irrigated E. globulus. Ecological Modelling 1999;117:125-41.

[22] Myers BJ, Theiveyanathan S, O'Brien ND, Bond JW. Growth and water-use of Eucalyptus grandis and Pinus radiata plantations irrigated with effluent. Tree Physiology 1996;16: 211-9.

[23] Myers BJ, Benyon RG, Theiveyanathan S, Criddle RS, Smith CJ, Falkiner RA. Response of effluent-irrigated Eucalyptus grandis and Pinus radiata to salinity and vapour pressure deficits. Tree Physiology 1998;18:565-73.

[24] Barrett DJ. Steady state turnover time of carbon in the Australian terrestrial biosphere. Global Biogeochemical Cycles 2002;16:1108-29.

[25] Vertessy RA, Zhang L, Dawes WR. Plantations, river flows and river salinity. Australian Forestry 2003;66:55-61.

[26] Potts BM, Reid JB. Tasmania's eucalypts: their place in science. Papers and Proceedings of the Royal Society of Tasmania 2003;137:21-37.

[27] Senelwa K, Sims REH. Fuel characteristics of short rotation forest biomass. Biomass and Bioenergy 1999;17:127-40. 
[28] Battaglia M, Sands PJ, Candy SG. Hybrid growth model to predict tree height and volume growth in young Eucalyptus globulus plantations. Forest Ecology and Management 1999;120:193-201.

[29] Battaglia M, Sands P. Modelling site productivity of Eucalyptus globulus in response to climatic and site factors. Australian Journal of Plant Physiology 1997;24:831-50.

[30] West PW. Tree and forest measurement. Berlin: Springer; 2004.
[31] West PW. Growing plantation forests. Berlin: Springer; 2006.

[32] Raymond CA, MacDonald AC. Where to shoot your pilodyn: within tree variation in basic density in plantations of Eucalyptus globulus and E. nitens in Tasmania. New Forests 1998;15:205-21.

[33] Ilic J, Boland D, McDonald M, Downes G, Blakemore P. Woody density phase 1-state of knowledge. National Carbon Accounting System, Technical report no. 18. Canberra: Australian Greenhouse Office; 2000. 